American Journal of Pharmacology and Toxicology 5 (3): 145-151, 2010

ISSN 1557-4962

(C) 2010 Science Publications

\title{
Acute and Sub-Acute Toxicological Assessment of Aqueous Leaf Extract of Bryophyllum Pinnatum (Lam.) in Sprague-Dawley Rats
}

\author{
${ }^{1}$ Raymond Iduojemu Ozolua, ${ }^{2}$ Sylvester Eshiotseme Idogun and ${ }^{1}$ Glory Eshiagiamhe Tafamel \\ ${ }^{1}$ Department of Pharmacology and Toxicology, Faculty of Pharmacy, \\ ${ }^{2}$ Department of Chemical Pathology, \\ University of Benin, P.M.B. 1154, Benin City 300001, Nigeria
}

\begin{abstract}
Problem statement: The aqueous leaf extract of Bryophyllum pinnatum has been reported to possess antihypertensive, antiinflammatory, antimicrobial, antidiabetic and antiulcer properties among others. Being readily available and easy to cultivate, the use of the plant in herbal medicine has been on the increase. Although there are few toxicological reports on the extract, these have not been sufficiently extensive. We therefore designed this study in order to evaluate more extensively the acute and sub-acute toxicity of the extract in rats. Approach: Oral and intraperitoneal (i.p) $\mathrm{LD}_{50}$ experiments were conducted on Sprague-Dawley rats. Other rats were given daily doses of $2 \mathrm{~g} \mathrm{~kg}^{-1}$ body weight (p.o) $\times 35$ days at the end of which kidneys, hearts, spleen and blood/sera were obtained for weight, haematological and biochemical analyses. Results: While there was no death at a maximum acute dose of $5 \mathrm{~g} \mathrm{~kg}^{-1}$ body weight by the oral route, the intraperitoneal $\mathrm{LD}_{50}$ was $1.8 \mathrm{~g} \mathrm{~kg}^{-1}$ body weight. Subacute treatment did not significantly alter animal weights, organ-to-body weight ratios, fluid intake, hematological indices and the levels of AST, ALP and albumin. ALT level was significantly reduced $(\mathrm{p}<0.03)$ in the treated group. Total bilirubin and conjugated bilirubin levels were not significantly altered in the treated group. Conclusion: The results point to the possible safety of the aqueous extract although more toxicological studies are needed to confirm this.
\end{abstract}

Key words: Bryophyllum pinnatum, herbal medicine, toxicity, safety profile, acute, sub-acute, Sprague-Dawley rats

\section{INTRODUCTION}

Herbal medicine has been gaining wide acceptance in recent times. One reason for this trend is the cost of orthodox medicines which put them beyond the reach of many people particularly in resource poor countries (Osujih, 1993; Cohen-Kohler, 2007). There has been the erroneous impression that herbal medicines have fewer adverse effects (Larrey, 1994; Chan, 2009). Although many of the claims ascribed to herbal medicines have not been proven scientifically, some herbs have been extensively studied thereby warranting their promotion as alternative to or complements of orthodox medicines. A major criticism associated with the use of herbal medicines is the absence of scientific evaluation of their safety profiles since many of them have turned out to be toxic (Ernst, 2005; Yeung et al., 2008). It is therefore pertinent that safety assessments should be conducted on natural products for which certain medicinal uses have been scientifically validated (Saad et al., 2006).
One of such widely used and studied plants is Bryophyllum pinnatum (Lam.) Oken (= Kalanchoe pinnata Pers) of the family Crassulaceae. It is commonly called air plant, Canterbury bells, cathedral bells, life plant, Mexican love plant, miracle plant and resurrection plant. It is found in many parts of the world largely because of its ease of cultivation which may also be the reason for its extensive promotion in herbal medicine. It is commonly found in the Southern part of Nigeria. The plant is a perennial glabrous herb with hollow stem. It is $50-200 \mathrm{~cm}$ high and rarely branches. The leaves appear to be the choicest part of the plant for medicinal purposes. The lower and uppermost leaves are simple but the middle ones are usually pinnately compound with 3-5 leaflets, opposite, flat and elliptic blades which are $5-20 \mathrm{~cm}$ long and $2-10 \mathrm{~cm}$ wide. The margins of the leaves are crenate and sometimes produce bulbils (Wagner and Sohmer, 1999). Phytoconstituents of the leaves include flavonoids, saponins, bufadienolide-type glycosides, tannins and alkaloids (Ojewole, 2005; Yamagishi et al., 1989).

Corresponding Author: Raymond Iduojemu Ozolua, Department of Pharmacology and Toxicology, Faculty of Pharmacy, University of Benin, P.M.B. 1154, Benin City 300001, Nigeria Tel: +234-802-352-8166 
The leaves have been reported to possess a variety of medicinal properties including antimicrobial (Akinpelu, 2000), antiulcer (Pal and Nag Chaudhuri, 1991), tocolytic (Gwehenberger et al., 2004; Plangger et al., 2006), antidiabetic (Ojewole, 2005), antiinflammatory and analgesic properties (Ojewole, 2005). Other reported properties include anti-tumor (Yamagishi et al., 1989; Obaseiki-Ebor et al., 1993), sedative and muscle relaxant effects (Yemitan and Salahdeen, 2005). It may also be effective in the treatment cutaneous leishmaniasis (Torres-Santos et al., 2003).

Verbal communications with herbalists in addition to internet searches indicate that the plant has gained popularity in herbal medicine. In spite of the useful properties, it seems that the safety profile of the plant has not been extensively studied. Reports exist of toxicity to cattle following consumption of large amounts (Reppas, 1995) and this may have been due to the bufadienolide constituent (McKenzie et al., 1987). Some workers (Torres-Santos et al., 2003) have evaluated few toxicological parameters using very low doses. A widely used plant such as $B$. pinnatum needs to be more extensively evaluated. Since most herbal remedies in developing countries are not standardized (Muhammad and Awaisu, 2008), it is pertinent to investigate the possible health implications following the ingestions of very high doses of plant extracts. Also, herbal medicines which are used for chronic diseases such as hypertension, diabetes and psychosis, ought to have their effects on hematological indices evaluated. We therefore undertook the present study in order to evaluate more extensively both the acute and sub-acute safety profiles of the aqueous leaf extract of the plant using rats.

\section{MATERIALS AND METHODS}

Plant material: Fresh leaves of $B$. pinnatum were collected from the wild in a suburb of Benin City, Nigeria, in June 2008. We confirmed that the plant was not exposed to herbicides. Although it is a commonly known plant, it was confirmed by Faculty Staff of the Department of Pharmacognosy, University of Benin, Nigeria. A herbarium specimen with voucher number FHI 107762 of the same plant has been deposited with the Forest Research Institute of Nigeria by Miss Joy Odimegwu. Adulterants were picked out and the leaves were thoroughly rinsed in tap water. The leaves $(2 \mathrm{~kg})$ were boiled in $4 \mathrm{~L}$ of distilled water for one hour, allowed to cool and then filtered two times with a clean white cloth. This followed the way local herbalists prepare the aqueous extract. The final filtrate which was free from particles was concentrated in a rotary evaporator and dried in an oven at $40^{\circ} \mathrm{C}$ over $24 \mathrm{~h}$ (yield $=3.6 \% \mathrm{w} / \mathrm{w}$ ) and then stored in amber-colored bottles in a fridge $\left(4^{\circ} \mathrm{C}\right)$. The aqueous extract was reconstituted in distilled water and administered according to the experimental protocol.

Animals: All experiments were performed using adult Sprague-Dawley rats of either sex weighing 200-240 g. The animals were bred locally in the departmental animal house, Department of Pharmacology and Toxicology, University of Benin, Benin City, Nigeria. They were housed in standard plastic cages and allowed access to rat pellets (Bendel Feeds and Flour Mill Ltd, Ewu, Nigeria) and tap water ad libitum. Animals were exposed to 12-h light/dark cycle with room temperature at $28.0 \pm 1.0^{\circ} \mathrm{C}$ and were handled according to standard protocols for the use of laboratory animals (National Institute of Health USA: Public Health Service Policy on Humane Care and Use of Laboratory Animals, 2002). The study was approved by Faculty of Pharmacy, University of Benin Ethical Committee on the use of animals for experiments.

Acute toxicological experiments: The oral or intraperitoneal median lethal dose $\left(\mathrm{LD}_{50}\right)$ of the aqueous extract of $B$. pinnatum was estimated by the Miller and Tainter method cited by Agil et al. (1995). For the oral route, six groups of rats comprising of 4 males and 4 females per group were used. Group 6 (control) was given the vehicle for extract reconstitution. Groups 1-5 were administered 1, 2, 3, 4 and $5 \mathrm{~g} \mathrm{~kg}^{-1}$ body weight of the extract respectively using orogastric tube (CUFNC16-3). Mortality and other signs of acute toxicity were monitored for $72 \mathrm{~h}$ and then 2 weeks after. This protocol was repeated by administering the extract intraperitoneally to another set of rats ( 8 per group) using doses of $0,1,1.5,2,2.5$ and $3.5 \mathrm{~g} \mathrm{~kg}^{-1}$ body weight for the control and groups 1-5 respectively. After the period of observation surviving animals were humanely killed by injecting excessive doses of thiopentone sodium.

Sub-acute toxicological experiments: Rats of either sex were selected into two groups of control $(n=8)$ and treated $(n=10)$, such that the number of either sex was the same in both groups but rats of opposite sex were not placed in the same cage and pregnant rats were excluded from the study. While the treated group was given $2 \mathrm{~g} \mathrm{~kg}^{-1}$ body weight (p.o) of extract, daily for 35 
days, the control group was sham-treated by giving each rat $0.4 \mathrm{~mL}$ of vehicle (p.o) daily for 35 days. The dose of the extract was chosen based on the method of Bautista et al. (2004).

On the 35th day, the animals were anaesthetized with diethyl ether vapor in a chamber and blood samples were withdrawn from the abdominal aortae for biochemical and hematological assays. The hearts, left kidneys and spleens were isolated, cleaned of the adherent tissues and kept on absorbent papers for 10 min before they were weighed.

Biochemical assays: In order to obtain serum, blood was allowed to clot and retract in specimen bottles without anticoagulant. The samples were centrifuged at 3000 revolutions per minute (rpm) and serum was separated by use of Pasteur pipettes into clear labeled bottles. The serum samples were stored in a deep freezer at $-20^{\circ} \mathrm{C}$ until analysis using Chemwell Chemistry auto analyzer (Awareness Technology, Model 2910). Alkaline phosphatase was measured using the method described by Raymond-Habecker and Lott (1995). Aspartate Aminotransferase (AST) and Alanine Aminotransferase (ALT) were assayed by the method described by Schumann et al. (2002). Serum bilirubin was quantified by Jendrassik-Grof method (Doumas and Wu, 1991). While total serum protein was assayed by the Biuret method (Doumas et al., 1981), serum albumin was quantified by the method of Doumas et al. (1971).

Haematological assays: White Blood Cell (WBC), Platelet Count (PC), Packed Cell Volume (PCV), Haemoglobin Concentration (HB) and the WBC differentials (Lymphocytes (LYM) and Neutrophils (NEU)) were all analyzed by use of an automated blood analyzer (QBC Autoread Plus, UK). The blood samples were first pipetted into QBC capillary tubes and spun in a parafuge centrifuge (Becton Dickson, UK) for $5 \mathrm{~min}$. The samples were thereafter placed one at a time in the autoread analyzer and values read off.

Measurement of body weight and daily fluid intake: In the course of 35 day treatment period, the fluid intake and body weights of the animals were recorded daily. Animals drank freely from graduated water bottles and at the same time each day, the decrement in the amount of fluid consumed over $24 \mathrm{~h}$ was measured by subtracting the day's reading from that of the previous day. Body weights of animals were recorded daily throughout the experimental period.

Chemicals: All chemicals and reagents used were of analytical grade and were obtained from internationally reputed suppliers such as Sigma (UK) and BDH (UK). Only freshly prepared solutions and reagents were used.

Statistics: Data are presented as mean \pm SEM (standard error of the mean) and $\mathrm{n}$ represents the number of rats per group. Comparisons were made between treated and control groups by use of Mann-Whitney test. All data were analyzed using GraphPad Prism software (UK). $\mathrm{p}<0.05$ indicates statistically significant difference.

\section{RESULTS}

The oral $\mathrm{LD}_{50}$ of the extract was indeterminable as there were no deaths recorded and no obvious toxicological signs at $5 \mathrm{~g} \mathrm{~kg}^{-1}$ body weight (Table 1). However, by the intraperitoneal route, the $\mathrm{LD}_{50}$ was estimated to be $1.8 \mathrm{~g} \mathrm{~kg}^{-1}$ body weight (Fig. 1). The surviving animals following i.p. injections exhibited signs of depression, reduced loco-motor activity, writhing but no diarrhoea although these signs were not quantified. Daily fluid intake, weight change and organto-body weight ratios were not significantly different between the control and treated groups after 35-day oral daily dosing with $2 \mathrm{~g} \mathrm{~kg}^{-1}$ body weight of the extract (Table 2).

Table 1: No-effect result of acute toxicological test on aqueous leaf extract of Bryophyllum pinnatum in rats

\begin{tabular}{llll}
\hline Dose $\left(\mathrm{g} \mathrm{kg}^{-1}\right)$ & Number of deaths & Mortality $(\%)$ & Symptoms \\
\hline 0 & $0 / 8$ & 0 & None \\
1 & $0 / 8$ & 0 & None \\
2 & $0 / 8$ & 0 & None \\
3 & $0 / 8$ & 0 & None \\
4 & $0 / 8$ & 0 & None \\
5 & $0 / 8$ & 0 & None \\
\hline
\end{tabular}

Animals were first observed for $72 \mathrm{~h}$ and then for 14 days after drug administration

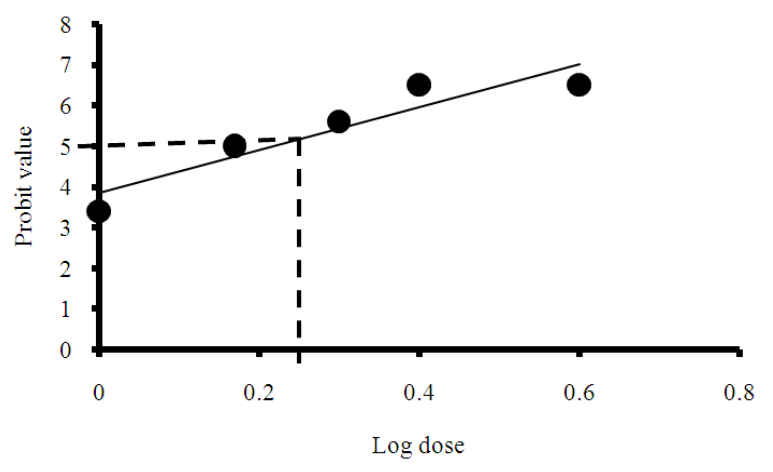

Fig. 1: Graphical estimation of intraperitoneal $\mathrm{LD}_{50}$ of the aqueous leaf extract of Bryophyllum pinnatum in rats. $\mathrm{LD}_{50}=1.8 \mathrm{mg} \mathrm{kg}^{-1} . \mathrm{n}=8$ rats per group 
Am. J. Pharm. \& Toxicol., 5 (3): 145-151, 2010

Table 2: Body weight indices and fluid intake following oral treatment with $2 \mathrm{~g} \mathrm{~kg}^{-1}$ body weight $\mathrm{day}^{-1}(\times 35)$ aqueous Bryophyllum pinnatum leaf extract

\begin{tabular}{llllll}
\hline & Weight change $(\%)$ & Daily fluid intake $(\mathrm{mL})$ & $\mathrm{H}: \mathrm{BW}\left(\times 10^{-4}\right)$ & $\mathrm{K}: \mathrm{BW}\left(\times 10^{-4}\right)$ & $\mathrm{S}: \mathrm{BW}\left(\times 10^{-4}\right)$ \\
\hline Control & $10.8 \pm 5.6$ & $107.5 \pm 6.3$ & $27.5 \pm 8.6$ & $27.8 \pm 1.2$ & $40.4 \pm 1.6$ \\
Treated & $17.9 \pm 7.8$ & $111.9 \pm 3.3$ & $27.0 \pm 7.1$ & $27.3 \pm 1.0$ & $46.1 \pm 3.7$ \\
\hline
\end{tabular}

Values are not significantly different. H:BW, Heart-to-Body Weight ratio; K:BW, Kidney-to-Body Weight ratio; S:BW, Spleen-to-Body Weight ratio; $\mathrm{n}=8$ (control) or 10 (Treated)

Table 3: Haematological indices following 35 day daily treatment with $2 \mathrm{~g} \mathrm{~kg}^{-1}$ body weight (p.o.) aqueous Bryophyllum pinnatum leaf extract

\begin{tabular}{|c|c|c|c|c|c|c|}
\hline & $\mathrm{WBC}(\times 1000 / \mu \mathrm{L})$ & LYM (\%) & NEU (\%) & PCV (\%) & $\mathrm{HB}\left(\mathrm{g} \mathrm{dL}^{-1}\right)$ & $\mathrm{PC}\left(\times 1000 \mu \mathrm{L}^{-1}\right)$ \\
\hline Control & $13.5 \pm 1.3$ & $60.6 \pm 3.2$ & $25.8 \pm 3.1$ & $34.5 \pm 1.8$ & $12.1 \pm 0.4$ & $648.4 \pm 67.9$ \\
\hline Treated & $13.3 \pm 2.3$ & $60.8 \pm 3.2$ & $24.7 \pm 1.9$ & $31.7 \pm 1.1$ & & \\
\hline
\end{tabular}

Values are not significantly different. WBC: White Blood Cell Count; LYM: Lymphocytes; NEU: Neutrophils; PCV: Packed Cell Volume; HB:

Haemoglobin; PC: Platelet Count; $\mathrm{n}=8$ (control) or 10 (Treated)

Table 4: Effects of 35 day daily treatment with $2 \mathrm{~g} \mathrm{~kg}^{-1}$ body weight (p.o.) aqueous leaf extract of Bryophyllum pinnatum on some biochemical parameters

\begin{tabular}{|c|c|c|c|c|c|c|c|}
\hline & T. BIL $\left(\mathrm{mg} \mathrm{dL}^{-1}\right)$ & C. BIL $\left(\mathrm{mg} \mathrm{dL}^{-1}\right)$ & T. PROT $\left(\mathrm{mg} \mathrm{dL}^{-1}\right)$ & $\operatorname{ALB}\left(\mathrm{mg} \mathrm{dL}^{-1}\right)$ & $\operatorname{ALT}\left(\mathrm{IU} \mathrm{L}^{-1}\right)$ & $\operatorname{AST}\left(\mathrm{IU} \mathrm{L}^{-1}\right)$ & $\operatorname{ALP}\left(\mathrm{IU} \mathrm{L}^{-1}\right)$ \\
\hline & $2.0 \pm 0.4$ & $1.3 \pm 0.2$ & $6.7 \pm 0.7$ & $3.7 \pm 0.4$ & $73.1 \pm 17.6$ & $66.2 \pm 16.5$ & $46.8 \pm 2.7$ \\
\hline Treated & $0.9 \pm 0.5$ & $0.5 \pm 0.2$ & $6.7 \pm 1.0$ & $3.2 \pm 0.4$ & $28.0 \pm 5.4^{*}$ & $89.9 \pm 15.0$ & $45.9 \pm 3.7$ \\
\hline
\end{tabular}

*: $\mathrm{p}<0.03$ compared to value in column. T. BIL: Total Bilirubin; C.BIL: Conjugated Bilirubin; T. PROT: Total Protein; ALB: Albumin; ALT: Alanine Aminotransferase; ASP: Aspartate Aminotransferase; ALP: Alkaline Phosphatase; $\mathrm{n}=8$ (control) or 10 (Treated)

Haematological indices in the rat after sub-acute oral treatment with $2 \mathrm{~g} \mathrm{~kg}^{-1}$ body weight of the extract are presented in Table 3. White Blood Cell Count (WBC) and its differentials (lymphocytes and neutrophils), the haematocrit (Packed Cell Volume or PCV), Haemoglobin (HB) and Platelet Count (PC) were all not significantly altered by the treatment.

Also the treatment did not significantly affect total protein and serum albumin concentrations (Table 4). Although total and conjugated bilirubin levels were reduced in the extract-treated animals, these were not significantly different from their corresponding control values. Table 4 also shows that serum AST and ALP were not significantly different between extract-treated group and control, but ALT was significantly $(\mathrm{p}<0.03)$ reduced in the treated group.

\section{DISCUSSION}

In spite of several criticisms, $\mathrm{LD}_{50}$ determination has remained a useful tool in safety assessment of substances (Shivananda Nayak et al., 2009). Absence of death and gross toxicological manifestations after an oral dose of 5 $\mathrm{g} \mathrm{kg}^{-1}$ body weight suggests that the extract may be largely safe by this route (Angeles-López et al., 2010; Krishnaraju et al., 2009). Although acute ingestion of quantities as high as $20 \mathrm{~g} \mathrm{~kg}^{-1}$ body weight of the leaves have been reported to be toxic to cattle (Reppas, 1995), our literature search has put the highest dose for experimental study at $800 \mathrm{mg} \mathrm{kg}^{-1}$ body weight in its analgesic and antiinflammatory activities in mice and rats (Ojewole, 2005). Apart from Plangger et al. (2006) who have explored the use of the extract as a tocolytic agent in humans, other studies involving the extract have been by use of the oral route. Infusion of $30 \mathrm{mg}$ $\mathrm{h}^{-1}$ of the extract to humans over $48 \mathrm{~h}$ by Plangger et al. (2006) did not result in any adverse effect to the mother or foetus. Thus, the intraperitoneal $\mathrm{LD}_{50}$ value of $1.8 \mathrm{~g}$ $\mathrm{kg}^{-1}$ body weight from this study is much higher than what might be necessary if the extract were to be administered by this route for therapeutic purposes. These workers (Plangger et al., 2006) reported that the extract was better tolerated than beta-agonists as intravenous tocolytic agents.

Herbalists in Benin City, Nigeria dissolve the yield of extract in $4 \mathrm{~L}$ of distilled water and adult patients are asked to take 30 to $40 \mathrm{~mL}$ a day in divided doses. This gives a daily dose range of 27-36 $\mathrm{mg}$ per day. Therefore, the maximum dose used in the $\mathrm{LD}_{50}$ determination ( $5 \mathrm{~g} \mathrm{~kg}^{-1}$ body weight) in this study is more than 130 times the recommended daily dose for adults. Similarly, the dose of $2 \mathrm{~g} \mathrm{~kg}^{-1}$ body weight per day used in the sub-acute toxicity test is more than 50 times the recommended daily dose for adults. TorresSantos et al. (2003) had reported no-adverse-effect following the use of $30 \mathrm{~g}$ wet weight of the leaves for 14 days for the treatment of human cutaneous leishmaniasis. Taking the physiological weight of a man to be $70 \mathrm{~kg}$, this is about $0.43 \mathrm{~g} \mathrm{~kg}^{-1}$ of the wet leaves per day. This dose is a lot smaller than the $2 \mathrm{~g}$ $\mathrm{kg}^{-1}$ of the dry extract per day for 35 days used in the present study. The use of much higher doses in toxicological tests gives an idea of the safety margin of the extract (Ozolua et al., 2009).

Diseases associated with the kidney often manifest as water imbalance with alteration in fluid intake 
following polyuria or oliguria (Alcázar Arroyo, 2008). Since there was no change in fluid intake by the animals given $2 \mathrm{~g} \mathrm{~kg}^{-1}$ body weight, it may be inferred that the dose of extract may not have caused any renal damage. Organ-to-body weight ratios are indices which are often used in toxicological evaluations (Michael et al., 2007) but they do not necessarily indicate the absence of lesions. These ratios did not change with sub-acute treatment of the animals. Presence of tumors and hyperplasias may change these ratios although definite genotoxicity such as by the use of Salmonella typhimurium is often necessary to evaluate carcinogenic potentials of substances (National Toxicology Program, 1993). The plant has even been shown to possess anti-tumor properties (Yamagishi et al., 1989; Obaseiki-Ebor et al., 1993).

Haematological changes are often accompaniments of neoplasms (Pelegrí, 2007) and bone marrow toxicity (Flanagan and Dunk, 2008) among other causes. The lack-of-effect on neutrophil levels indicates that the extract did not induce any inflammatory process since these cells are usually elevated in the course of inflammations (Zhang et al., 2010). The aqueous leaf extract of the plant has been shown to possess antiinflammatory property (Ojewole, 2005)-an action which could depend at least in part on its ability to inhibit the proliferation of pro-inflammatory cells and formation of pro-inflammatory autacoids.

Elevated levels of bilirubin, AST, ALT and ALP are often diagnostic of underlying cellular injuries (Karthikeyan et al., 2006; Wittekind, 1995). In the present study, these parameters are comparable between the control and treated groups except for ALT which was significantly reduced in the treated group. The reduced level of total and conjugated bilirubin taken together with the reduced level of ALT in the extract-treated group lends explanations to the reported hepatoprotective properties of the extract (Yadav and Dixit, 2003).

Constituents of B. pinnatum such as flavonoids and ascorbic acid are natural anti-oxidants which can prevent cell damage and the pathological consequences. These constituents may have been responsible for the many ethnomedicinal uses of the plant in addition to increasing the safety margin of the extract. For example, flavonoids as water-soluble antioxidants are free radical scavengers which prevent oxidative cell damage thereby demonstrating strong anticancer properties (Salah et al., 1995).

\section{CONCLUSION}

In conclusion, all the parameters evaluated in this study point to the possible safety of aqueous leaf extract of
B. pinnatum for the indicated medicinal purposes at doses as high as $2 \mathrm{~g} \mathrm{~kg}^{-1}$. Further toxicological studies would be necessary in order to confirm the safety of this extract.

\section{ACKNOWLEDGEMENT}

The researchers grateful to Mr. J. Abanum and Mrs. C. Etamesor for their care of the animals. The assistance of the technical staff of the Departments of Pharmacognosy, Haematology and Chemical Pathology is appreciated. There are no conflicts of interest whatsoever in the planning and execution of the study. No funding was received for the execution of the study.

\section{REFERENCES}

Akinpelu, D.A., 2000. Antimicrobial activity of Bryophyllum pinnatum leaves. Fitoterapia, 71: 193-194. PMID: 10727819

Agil, M.A., S. Risco, M. Miró, M.C. Navarro and M.A. Ocete et al., 1995. Analgesic and antipyretic effects of Ecballium elaterium (L.) A. Richard. Extract in rodents. Phytother. Res., 9: 135-138. DOI: 10.1002/ptr.2650090211

Angeles-López, G., A. Pérez-Vásquez, F. HernándezLuis, M. Déciga-Campos and R. Bye et al., 2010. Antinociceptive effect of extracts and compounds from Hofmeisteria schaffneri. J. Ethnopharmacol., 131: 425-432. DOI: 10.1016/j.jep.2010.07.009

Alcázar Arroyo, R., 2008. Electrolyte and acid-base balance disorders in advanced chronic kidney disease. Nefrologia, 28: 87-93. PMID: 19018744

Bautista, A.R., E.L. Moreira, M.S. Batista, M.S. Miranda and I.C. Gomes, 2004. Subacute toxicity assessment of annatto in rat. Food Chem. Toxicol., 42: 625-629. PMID: 15019187

Chan, T.Y.K., 2009. Potential risks associated with the use of herbal anti-obesity products. Drug Safe., 32: 453-456.

Cohen-Kohler, J.C., 2007. The morally uncomfortable global drug gap. Clin. Pharmacol. Ther., 84: 610-614. PMID: 17898710

Doumas, B.T. and T.W. Wu, 1991. The measurement of bilirubin fractions in serum. Crit. Rev. Clin. Lab. Sci., 28: 415-445. PMID: 1772588

Doumas, B.T., D.D. Bayse, R.J. Carter, T. Peters Jr. and R. Schaffer, 1981. A candidate reference method for determination of total protein in serum: I development and validation. Clin. Chem., 27: 1642-1650. PMID: 6169466

Doumas, B.T., W.A. Watson and H.G. Biggs, 1971. Albumin standards and the measurement of serum albumin with bromocresol green. Clin. Chim. Acta, 31: 87-96. PMID: 5544065 
Ernst, E., 2005. The efficacy of herbal medicine-an overview. Fund. Clin. Pharmacol., 19: 405-409. DOI: $10.1111 / \mathrm{j} .1472-8206.2005 .00335 . x$

Flanagan, R.J. and L. Dunk, 2008. Haematological toxicity of drugs used in psychiatry. Hum. Psychopharmacol. Clin. Exp., 23: 27-41. DOI: 10.1002/hup.917

Gwehenberger, B., L. Rist, R. Huch and U. von mandach, 2004. Effect of Bryophyllum pinnatum versus fenoterol on uterine contractility. Eur. J. Obstet. Gynecol. Reprod. Biol., 113: 164-171. PMID: 15063954

Karthikeyan, S., K. Gobianand, K. Pradeep, C.V. Mohan and M.P. Balasubramanian, 2006. Biochemical changes in serum, lung, heart and spleen tissues of mice exposed to sub-acute toxic inhalation of mosquito repellent mat vapor. J. Environ. Biol., 27: 355-358. PMID: 17436523

Krishnaraju, A.V., C.B.M. Rao, D. Sundararaju, K. Sengupta and G. Trimurtulu, 2009. Antiinflammatory activity of Vitex leucoxylon L. bark extracts against Freund's complete adjuvant induced arthritis in Sprague Dawley rat. Am. J. Infect. Dis., 5: 68-73. DOI: 10.3844/ajidsp.2009.68.73

Larrey, D., 1994. Liver involvement in the course of phytotherapy. Presse Med., 23: 691-693. PMID: 8072973.

McKenzie, R.A., F.P. Franke and P.J. Dunster, 1987. The toxicity to cattle and bufadienolide content of six Bryophyllum species. Aust. Vet. J., 64: 298-301. PMID: 3439945

Michael, B., B. Yano, R.S. Sellers, R. Perry and D. Morton et al., 2007. Evaluation of organ weights for rodent and non-rodent toxicity studies: A review of regulatory guidelines and a survey of current practices. Toxicol. Pathol., 35: 742-750. PMID: 17849357

Muhammad, B.Y. and A. Awaisu, 2008. The need for enhancement of research, development and commercialization of natural medicinal products in Nigeria: Lessons from the Malaysian experience. Afr. J. Tradit. Comp. Altern. Med., 5: 120-130. PMID: 20161927

National Toxicology Program, 1993. Toxicology and Carcinogenesis Studies of Mercuric Chloride (CAS No. 7487-94-7) in F344 Rats and B6C3F1 Mice (Gavage Studies). Natl. Toxicol. Program Tech. Rep. Ser. 408. pp: 1-260. PMID: 12621522

Obaseiki-Ebor, E.E., K. Odukoya, H. Telikepalli, L.A. Mitscher and D.M. Shankel, 1993. Antimutagenic activity of extracts of leaves of four common edible vegetable plants in Nigeria (West Africa). Mutat. Res., 302: 109-117. PMID: 7684505
Ojewole, J.A., 2005. Antinociceptive, antiinflammatory and antidiabetic effects of Bryophyllum pinnatum (Crassulaceae) leaf aqueous extract. J. Ethnopharmacol., 99: 13-19. PMID: 15848014

Osujih, M., 1993. Exploration of the frontiers of tradomedical practices: Basis for development of alternative medical healthcare services in developing countries. J. R. Soc. Health, 113: 190-194. PMID: 8410912

Ozolua, R.I., O.N. Anaka, S.O. Okpo and S.E. Idogun, 2009. Acute and sub-acute toxicological assessment of the aqueous seed extract of Persea americana Mill (Lauraceae) in Sprague-Dawley rats. Afr. J. Trad. CAM., 6: 573-578.

Pal, S. and A.K. Nag Chaudhuri, 1991. Studies on the antiulcer activity of a Bryophyllum pinnatum leaf extract in experimental animals. J. Ethnopharmacol., 33: 97-102. PMID: 1943181

Pelegrí, A., 2007. Impact of erythropoietin treatment on the quality of life of oncologic patients. Clin. Transl. Oncol., 9: 645-651. PMID: 17974525

Plangger, N., L. Rist, R. Zimmermann and U. von mandach, 2006. Intravenous tocolysis with Bryophyllum pinnatum is better tolerated than betaagonist application. Eur. J. Obstet. Gynecol. Reprod. Biol., 124: 168-172. PMID: 16051414

Raymond-Habecker, J. and J.A. Lott, 1995. Principle of Analysis of Alkaline Phosphatase. In: Clinical Chemistry, Theory, Analysis and Correlation, Kaplan, L.A., A. Pesce and S. Kazmierczak (Eds.). Mosby, St. Louis, ISBN: 0323017169, pp: 521-522.

Reppas, G.P., 1995. Bryophyllum pinnatum poisoning of cattle. Aust. Vet. J., 72: 425-427. DOI: 10.1111/j.1751-0813.1995.tb06194.x

Saad, B., H. Azaizeh, G. Abu-Hijleh and O. Said, 2006. Safety of traditional Arab herbal medicine. Evid. Based Comp. Alternat. Med., 3: 433-439. PMID: 17173106

Salah, N., N.J. Miller, G. Paganga, L. Tijburg and G.P. Bolwell et al., 1995. Polyphenolic flavanols as scavengers of aqueous phase radicals and as chainbreaking antioxidants. Arch. Biochem. Biophys., 322: 339-346. DOI: 10.1006/abbi.1995.1473

Schumann, G., R. Bonora, F. Ceriotti, G. Ferard and C.A. Ferrero et al., 2002. IFCC primary reference procedures for the measurement of catalytic activity concentrations of enzymes at 37 degrees $\mathrm{C}$. International Federation of Clinical Chemistry and Laboratory Medicine. Part 5. Reference procedure for the measurement of catalytic concentration of aspartate aminotransferase. Clin. Chem. Lab. Med., 40: 725-733. PMID: 12241022 
Shivananda Nayak, B., S. Sandiford and A. Maxwell, 2009. Evaluation of the wound-healing activity of ethanolic extract of Morinda citrifolia L. Leaf. Evid.-Based Comp. Alternat. Med., 6: 351-356. DOI: $10.1093 /$ ecam/nem127

Torres-Santos, E.C., S.A. Da Silva, S.S. Costa, A.P. Santos and B. Rossi-Bergmann et al., 2003. Toxicological analysis and effectiveness of oral Kalanchoe pinnata on a human case of cutaneous leishmaniasis. Phytother. Res., 17: 801-803. PMID: 12916081

Wagner, W.L. and S.H. Sohmer, 1999. Manual of the Flowering Plants of Hawaii. 1st Edn., University of Hawaii Press, Honolulu, ISBN: 10: 0824821661, pp: 1948.

Wittekind, C., 1995. Prognostic factors in liver tumors. Verh. Dtsch. Ges. Pathol., 79: 109-115. PMID: 8600673

Yadav, N.P. and V.K. Dixit, 2003. Hepatoprotective activity of the leaves of Kalanchoe pinnata Pers. J. Ethnopharmacol., 86: 197-202. PMID: 12738087
Yamagishi, T., M. Haruna, X.Z. Yan, J.J. Chang and K.H. Lee, 1989. Antitumor agents, 110. Bryophyllin B, a novel potent cytotoxic bufadienolide from Bryophyllum pinnatum. J. Nat. Prod., 52: 1071-1079. PMID: 2607348

Yemitan, O.K. and H.M. Salahdeen, 2005. Neurosedative and muscle relaxant activities of aqueous extract of Bryophyllum pinnatum. Fitoterapia, 76: 187-193. PMID: 15752629

Yeung, K.S., J. Gubili and B. Cassileth, 2008. Evidence-based botanical research: Applications and challenges. Hematol. Oncol. Clin. North Am., 22: 661-670. PMID: 18638694

Zhang, W., L. Fievez, E. Cheu, F. Bureau and W. Rong et al., 2010. Anti-inflammatory effects of formoterol and ipratropium bromide against acute cadmium-induced pulmonary inflammation in rats. Eur. J. Pharmacol., 628: 171-178. PMID: 19925785 